\title{
Research on Issues of Legal Supervision on Deal on Credit
}

\author{
Fuling Ding \\ Sichuan University \\ Chengdu, China
}

\begin{abstract}
Deal on credit, namely margin trading has developed rapidly in recent years, which serves as an opportunity and a challenge for the capital market in China. Although the State Council, China Securities Regulatory Commission, and the exchange made a series of institutional arrangements for margin trading, deal on credit is still a new thing for the capital market in China since there are still some problems in construction of legal system and responsibility system of supervision on deal on credit. Based on the supervision practice of deal on credit in China, this paper proposes that we should treat the view of "non-administrative penalty administrative supervision measures" and administrative responsibility cannot replace civil liability. It also puts forward the measures and suggestions to complete the supervision on deal on credit from the level of legal rules and administrative responsibility, so as to improve the effectiveness of supervision and maintain the sound and stable development of capital market in China.
\end{abstract}

Keywords-margin trading; legal nature of guarantee; administrative supervision mea sures; investor eligibility

\section{INTRODUCTION}

Deal on credit (securities marg in trading) is relative to the spot transaction of one-time "delivery versus payment". As the realization form of cred it economy, it is an extension of the credit in securities market as well as the expression of highly developed economy. [1]"In a broad sense, deal on credit includes the credit that the buyer and seller give to each other involved in margin trading (such as the futures trading of European continent), the credit loaned by securities dealers for securities margin trading (such as margin trading and short selling in the US), and non-purpose loan loaned by banks for customers or securities and even options of security trading engage in non-purpose loans or even for securities trading. In the narrow sense, it only refers to the loan business from securities dealers or securities and financial institutions to customers." [2] The deal on credit in this article only refers to the narrow sense, that is, "margin trading." "Margin trading, also known as marg in trade and buying on margin, which refers to the business activities that the securities companies lend money to customers for their purchase of securities or loan securities for sale. [3] Marg in trading is conducive to improving market liquidity [4], but the characteristics of high leverage and high risk of marg in trading will also bring a greater impact to the market. Marg in trading is an innovative business for our country. Its introduction is both an opportunity and a challenge for the development of capital market in China. At present, China has initially set up the basic system of supervision on deal on credit, but whether the basis of laws and regulations or the responsibility system still has some problems and need further solution.

\section{THE PROBLEMS OF SUPERVISION ON DEAL ON CREDIT}

\section{A. The Level of Effectiveness of Supervision Law of Deal on Credit is Low}

Although the "Securities Law" and "Supervision Regulations of Securities Company " have regulated the margin trading, in the process of supervision and market operation, we can directly refer to the "administrative measures of margin trading business in securities companies" (hereinafter referred to as "administrative measures of margin trading"). As the direct basis of margin trading, "administrative measures of margin trading" does not belong to law and admin istrative regulation, with the lower level of effectiveness, which is not conducive to the supervision of margin trading as well as the protection for investors. Inconsistent processing result is easy to appear in the supervision and judicial practice. For example, in "appeal case of margin trading dispute between Xinyu Tonglin Investment Consulting Co., Ltd. and Xu Wenbin" in Jiangxi Province, court of first instance holds that the plaintiff and defendant take the mutual cooperation in investing stock to disguise margin trading, of which the contract is in violation of "pilot management method of margin trading business in securities company" and thus it is invalid. [5] However, the author believes that "pilot management method of marg in trading business in Securities Company" does not belong to admin istrative regulations, so it cannot be used as the bas is for judging the contract invalid. In accordance with the regulations of the contract law, the contract in violation of mandatory provisions of laws and administrative regulations is invalid. Therefore, we should take the regulation of "securities law" and "supervision and management regulations of Securities Company" as the bas is to invalidate the invalid. This view is also confirmed in the judgment of court of second instance. This case reflects two issues. One is the "administrative measures of marg in trading" stipulates the rights and obligations of investors and securities companies. If there is a dispute, investors will resort to "administrative measures of margin trading" for judicial 
relief, which may cause the negative situation for investors; Second is the judicial department may fail to find a legal basis when dealing with margin trading disputes due to the lack of provisions of the upper law and lower level of effectiveness of "adminis trative measures of marg in trading".

\section{B. Legal Effect of Regulation and Normative Documents of Margin Trading is Unknown}

Capital market continues to innovate and innovative business continues to emerge. It is hard for the basic laws such as Securities Act to make specific provisions for all businesses, so legal provisions often lag behind the development of market. Therefore, China Securities Regulatory Commission has developed a large number of regulations and normative documents. The most prominent problem in practice is that the laws and regulations make principle provisions for a certain issue while regulation and normative documents formulate operational details. Are the consequences of violating these operational details and that of violating laws and regulations the same? For example, Article 4 of the administrative measures of margin trading business in securities companies stipulates the prohibited acts of margin trading business in securities companies. If the securities companies violate these prohibited provisions, is the nature the same to violation of the Regulations on Supervision and Administration of Securities Companies, Securities law "? The author agrees that the regulations and normative document are the main approaches of implementation of basic laws and regulations, which needs us to confirm the legal consequences of violating its provision according to different circumstances. First is violation of the regulations and normative document that has clear and direct authority of laws and regulations, which should be regard as violation of laws and regulations; second is violation of laws and regulations that has principle provisions but without regulations and normative document that has clear and direct authority the laws and regulations, of which the legal consequences should be different from that of violation of laws and regulations; third is that if the regulations and normative document is in violation of the purpose of laws and regulations, these provisions themselves are invalid. [6]

\section{The Legal Nature of the Administrative Regulatory Measures of Deal on Credit is Doubtful}

Article 49 of the administrative measures of margin trading stipulates that for the securities company or its branches that violates the provisions of this measures, CSRC or its agencies may take related supervision measures including ordering to correct, regulatory talks, issuing a warning letter, ordering to state openly, ordering to attend training, ordering to report regularly, suspending accepting any documents related to administrative license, suspending part or all of its business, and revoke the business license. In 2002, China Securities Regulatory Commission firstly proposed the concept of "non-administrative penalty measures" in the Notice on Further Improving the Administrative Punishment System of China Securities Regulatory Commission and made procedure stipulations for non-administrative penalty measures different from admin istrative penalty. However, since the legal nature of administrative supervision measures is inconclusive, its effectiveness and the relationship between it and admin istrative penalty and administrative coercive measures still need further discussion.

First of all, the legal nature of non-admin is trative penalty supervision measures should not only be judged from the name, but should be considered comprehensively by combining with the characteristics and consequences of supervision measures, including the substantial influence on rights, obligations, rights and interests of supervision target. The author thinks that the non-administrative penalty supervision measures should be divided into three categories according to their characteristics and substantial influence. The first category is the supervision measures with the characteristics of administrative penalty, such as the "revocation of business license" stipulated in Article 49 of the administrative measures of margin trading, and the "revocation of the license" stipulated in Article 8 of "Administrative Punishment Law", which can exert substantial influence on the object of punishment will have a substantial impact on the business qualification of the object of penalty, so excluding the supervision measures of "revocation of business license" from the Administrative Punishment Law is hard to be persuasive. The second category is the supervision measures with the characteristic of admin istrative coercive measures, such as the Article 56 of "Admin istrative Regulations on Futures Trading" and Article 34 of "administrative measures of risk management indicators in Futures Company" stipulating the supervision measures of "restrictions on the transfer of property or setting other rights in the property", which obviously implements "temporary restrictions" on the property of citizens, protects the realization of rights and obligations decided and set by administration and conforms to administrative coercive measures essentially. The third category is the supervision measures that is adopted by CSRC to exert supervisory authority and can't be classified as administrative penalty and administrative coercion. For example, Article 49 of "administrative measures of marg in trading" stipulates "regulatory talks", of which the substantial influence on the supervision target is clearly different from the above-mentioned two types of measures. If they are all classified into one category and treated equally, it is unfair legally and theoretically.

Second, "administrative measures of margin trading" provides the measure of "revocation of business license", but the author believes that the scope of supervision measures of "administrative measures of margin trading" should not exceed the provisions of the host law of "regulations of Supervision and administration in securities companies". However, "regulations of Supervision and admin istration in securities companies" does not provide the supervision measures of "revocation of the business license".

\section{Administrative Penalty Lacks Grades}

First, administrative penalty should be compatible with administrative violation. Proportionality requires the admin istrative organ to take into account the realization of 
the administrative objectives and protect the rights and interests of counterparts when imposing an administrative act. For example, if the realization of admin istrative objectives may have any adverse effect on the rights and interests of counterparts, they should limit this adverse effect into the range as small as possible. [7] The "administrative measures of marg in trading" doesn't illustrate the specific application situation of each kind of supervision measures, and there is no construction of punishment system with grades that illegal behavior and punishment severity match each other, so it given the supervision department too much discretion, which may cause the power rent-seeking. The enforcement agencies of supervision measures are mostly CSRC agencies, so if there is no clear basis for the decision, it is not conducive to the unity of administrative supervision measures. Second, there are many situations that obligations and responsibilities are imbalanced in the "Securities Law", "Securities Company Supervision and Management Regulations" and "margin management approach". There are obligations without responsibilities, leading supervision enforcement to lack legal basis.

\section{SUGGESTIONS ON IMPROVEMENT OF SUPERVISION ON DEAL ON CREDIT IN CHINA}

\section{A. Improve the Subject System of Supervision on Deal on Credit}

Deal on credit has challenged the orderliness and security of securities market transactions. In order to prevent excessive credit in the securities market and abnormal fluctuations in the market, an effective hierarchical supervision system of deal on credit should be established. It is recommended that the securities regulatory authority serve as the subject of centralized supervision and establish a supervision and coordination mechanism with self-discipline associations, exchanges, registration and settlement companies and China securities finance co. LTD. In particular, they should clarify the specific supervision scope and responsibilities of each supervis ory subject, effectively regulate the subject behavior of deal on credit and safeguard the sound development of the securities market.

\section{B. Improve the Laws and Regulations System of Deal on Credit}

Deal on credit is a high-risk transaction. From the overseas experience, it is necessary to stipulate strict laws and regulations and establish detailed operating procedures and strict regulatory system. We should improve the laws and regulations system of supervision and make clear the obligation and responsibility, so that the obligation and responsibility will match each other to provide a clear basis of enforcement for regulation enforcement. Although the flexibility of regulations and normative documents plays an important role in the initial stage of legal regulation of deal on credit, with the continuous expansion of business scale and the deepening of social influence, we should pay more attention to the convergence of the host laws and other department laws, improve the legal level of supervis ory law, and normalize the deal on credit behavior more scrupulously.

\section{Improve the Administrative Responsibility System of Deal on Credit}

The admin is trative res ponsibility system of deal on credit is an important foothold of supervision on deal on credit, so it is necessary to establish an administrative responsibility system with clear grades. This responsibility system includes the responsibility system of administrative counterparts as well as the administrative law enforcement to form the normative system where the rights, responsibilities and benefits are consistent, so that the behavior and responsibility are equal, instead of the unbalanced responsibility.

\section{Regard the Administrative Supervision Measures Dialectically}

"Administrative Punishment Law" in China does not make clear the connotation of "administrative penalty", but makes detailed division of classification of punishment by enumerating. With the continuous development of social economy, enumerated legislative means inevitably has defect. The "non-administrative penalty measures" of CSRC is a specific concept that appears during the period after the introduction of the Administrative Punishment Law and before the introduction of other special regulations. [8]The supervision measures of the CSRC have their practical significance, which plays an important role in restricting the illegal acts in capital market. However, the practice of replacing administrative penalty with supervision measures is always contrary to the spirit of law. We should formulate regulatory measures strictly in accordance with the spirit of law. The rules and regulations of Article 12 of "Administrative Punishment Law" can make specific provisions in the scope of behavior, type and extent of administrative penalty given by laws and administrative regulations. The supervision measures stipulated in accordance with the spirit, regulations, and normative documents of this provision should also be within the scope of the types and ranges of supervision measures stipulated by laws and administrative regulations. At the same time, different types of regulatory measures should be treated differently.

\section{CONCLUSION}

The development of deal on credit cannot be achieved overnight. Deal on credit in many countries has experienced twists and turns, and has been adjusted continuously in the process of regulation of the government to ultimately build the supervision legal system for margin trading in local region. The supervision system of deal on credit not only includes the legal system composed of laws, administrative regulations, regulations, normative documents and selfdiscipline rules, market rules and so on, but also includes the supervisory system formed by the supervising subjects and their coordination and division of labor. To give full play to the value function of deal on credit, we need to lay a better legal basis and provide a better legal environment for the development of deal on credit, and fully protect the legitimate rights and interests of investors. It is very 
necessary to establish detailed operating procedures and strict supervision system.

\section{REFERENCES}

[1] (America) Frank Frank J.Fabozzi, Steven V. mann . Securities Finance - Margin trading and Repurchase Agreement, tr. Song Guanghui, Li Nan, Tian Jinhua, China MachinePress, 2014 (1).

[2] Qi Meng. Research on the Supervision Legal System of Margin Trading, Law Press, 2013 (7)

[3] Jiang Mingan. Administrative Law and Administrative Litigation Law, Peking University Press, 201 1,8 (5), pp.74

[4] Zhang Wancheng. Research on deal on credit in China 's Securities Market, Yunnan University Press, 2008,7 (1)

[5] Liu Qichang. System and Operation Securities deal on credit, Karen press, Taiwan 1986. pp: 1

[6] Zhang Yue, Chen Xiaobao. Analysis on the Legal Relationship of Margin Trading, Finance and Economics, 2012, 7

[7] Huang Jiangdong. The Current Situation, Problems and Perfection of the Legal Liability System of Margin Trading. 2012, 6. pp: 321-336

[8] Huang Jiangdong. Comparison and Reference of Risk Supervision on Margin Trading, company law review, 2012

[9] Huang Jiangdong. Legal Relationship of Margin Trading Law and Analysis of Its Dual Struct ure, financial laws, 2012.9 (433)

[10] Pecking University Law, Civil Judgment of Intermediate People's Court in Xinyu, Jiangxi Province (2015) No.3 Xinyu civil second final judgement, http://scslsxh.chinalawinfo.com/case/display content .asp?Gid=121663 982\&Keyword=margin trading, visit on Feb. 26, 2016.

[11] Lawtime. A Study on Non-administrative Punitive Supervision Measures of China Securities Regulatory Commission, http://www.lawtime.cn/info/minshi/mssslunwen/2011121574621 htm 1, visit on Mar. 2, 2016 